\title{
EYA1 Gene
}

National Cancer Institute

\section{Source}

National Cancer Institute. EYA1 Gene. NCI Thesaurus. Code C75390.

This gene may play a role in organ development. 